\title{
SEASONAL CHANGES IN PHOSPHORUS LOAD FLOWING OUT OF SMALL AGRICULTURAL CATCHMENTS
}

\author{
Krzysztof Pulikowski', Katarzyna Pawęska', Aleksandra Bawiec ${ }^{1}$ \\ 1 Institute of Environmental Engineering, Wrocław University of Environmental and Life Sciences, pl. Grun- \\ waldzki 24, 50-363 Wrocław, Poland, e-mail: krzysztof.pulikowski@up.wroc.pl
}

Received: 2014.09.21

Accepted: 2014.10.27

Published: 2015.01.02

\begin{abstract}
In this article distribution of monthly phosphorus loads flowing out of two agricultural catchments which are located in different physiographic conditions of Lower Silesia was analysed. Loads of phosphorus runoff from the catchment located in the piedmont part of Lower Silesia in each month rarely exceed $0.10 \mathrm{~kg} \mathrm{P} \cdot \mathrm{ha}^{-1}$. The size of annual load is determined by loads obtained in two months of early spring. Much lower loads obtained for lowland catchment, located near Wroclaw. Values calculated for each month rarely exceed the value of $0.01 \mathrm{~kg} \mathrm{P} \cdot \mathrm{ha}^{-1}$. Culmination of loads bringing away is a bit more extended in a time compared to the catchment located on Sudety Mts. Foreland. Much higher loads are observed during the period from January to April this period has a major impact on the size of phosphorus load that flows out from this catchment during whole hydrological year.

The obtained results clearly indicate that the threat of watercourses and water reservoirs supply in phosphorus compounds from agricultural land is periodic and it is particularly high during early spring. Phosphorus load flowing out from the analyzed catchments is very diverse. From facility located on Sudety Foothill in hydrological year, during research period, flowed away average $0.81 \mathrm{~kg} \mathrm{P} \cdot \mathrm{ha}^{-1}$. Significantly lower values were obtained for second facility and it was average $0.15 \mathrm{~kg} \mathrm{P} \cdot \mathrm{ha}^{-1}$ during a year. The size of load discharged during a year is largely determined by amount of phosphorus load flowing out during winter half of the year (from XI to IV). In case of foothill catchment in this period flowed out average $0.56 \mathrm{~kg} \mathrm{P} \cdot \mathrm{ha}^{-1}$, which presents $69 \%$ of annual load and in lowland catchment this percentage was even slightly higher and was $73 \%$.
\end{abstract}

Keywords: water, catchment, season, load, phosphorus.

\section{INSTRODUCTION}

Phosphorus compounds flowing into surface water pose a significant risk of eutrophication, and thus contribute to the degradation of these resources. This significantly limited the usefulness of this kind of water to be used for various purposes like water supply of population and industry, recreation, etc. Supply of phosphorus to surface water as a limiting element of primary production should be subject to special control and restriction. Currently, much more attention is paid to reducing the flow of nitrogen into surface waters, especially in the nitrate form, which reduces their suitability for the use for purposes connected with supply of the population with drinking water.

One of the sources of phosphorus contaminating surface water is agricultural land [Pulikowski 2004; Sojka et al. 2008; Czaban 2009; ]. Phosphorus compounds used as fertilizers are adsorbed on soil particles and hardly dissolve in the soil. Phosphates enter into surface water with suspensions, mainly as a result of erosion. It is estimated that the loss of phosphorus during fields fertilization ranges from 0.1 to $5.0 \%$ and is a significant source of phosphorus in surface water [Dojlido 1995]. In breeding farms plants needs of phosphorus can be fully covered by natural fertilizers. Reduction of mineral fertilization ensures the reduction of ex- 
cess of this component in the soil, which poses a threat to groundwater, while not significantly affect the yield increase [Pietrzak 2005]. In most cases, a reduction in phosphorus fertilization does not reduce the profits of the farmer, but reduces costs, and it is always beneficial to the environment [Sapek 2008].

The phosphorus content in the water flowing from the small lowland catchments, in contrast to nitrate, has no relationship with the indicator of soils bonitation [Witkowski 1997] and content of phosphorus in the soil [Gardner 2002] but is correlated to the share of crops fields in catchment and inclines [Ekholm et al. 2000] as well as arable lands [Skorbiłowicz 2010]. The concentration of phosphorus also shows a positive (not always significant at $\mathrm{p}=0.05$ ) correlation with the volume of runoff [Pulikowski 2002], which confirms the high proportion of surface runoff in shaping the size of phosphorus load flowing out from the catchment. Runoff, groundwater and water captured in soil pores from areas located by the river are responsible for moving $98 \%$ of orthophosphate outflowing from the catchment [Banaszuk et al. 2009]. The average annual concentration of total phosphorus in lowland rivers may even exceed $2 \mathrm{mg} \mathrm{P} \cdot \mathrm{dm}^{-3}$ [Dąbrowska, 2008]. In case of catchment with disordered water and wastewater management an important source of phosphorus in surface water may be domestic wastewater discharged in an uncontrolled way [Pulikowski et al. 2011a].

Excess of phosphorus in surface water is a global problem. Phosphorus once introduced into the environment cumulates and can be removed only in the process of remediation [Sapek 2011]. One way to reduce the flow of this component into surface water may be the use of materials absorbing this component in wastewater treatment plants or reservoirs where runs pollutions from small agricultural catchments [Karczmarczyk, Bus 2014]. Another solution is to use on the inlet to the reservoir a small primary reservoir [Dąbrowska et al. 2014].

\section{RESEARCH METHODOLOGY}

The study analyzed the results of research carried out in three consecutive hydrological years 1999/2000, 2000/2002 and 2001/2002 at two different facilities located in the lower Silesia. One of them - Stare Bogaczowice - is located on the border of the Bolkow-Walbrzych Foothill and Wałbrzyskie Mountains, in the region of Central Sudetes. The study included ditch catchment with total area of 29 hectares. This catchment is situated 400-500 meters above sea level on the northern and north-eastern slopes. Declines of this area are very large, ranging from 5-8\%. The catchment area includes arable fields, partially drained [Pulikowski 2004]. During the study period rainfalls were higher than long-term average value $(655 \mathrm{~mm})$. Year $2001 / 2002$ is worth attention because during this period very high annual precipitation, up to 1044 $\mathrm{mm}$, was noted. This was connected to an extremely high rainfall that occurred in August (348 mm) (Table 1). The average annual temperature in each year was higher than the average of the long term and ranged from $8.4^{\circ} \mathrm{C}$ to $8.6^{\circ} \mathrm{C}$ (Table 2).

The second research facility (Szewce) is located in the Silesian Lowland near Wrocław. The property is situated in the catchment at an altitude of 114-132 $\mathrm{m}$ above sea level Declines in the area range from 2.5 to $4.0 \%$. The study included the catchment area of 100.7 hectares that is an arable land, of which nearly $40 \%$ is drained by drainage. On this area occur brown soils with particle size of light and medium loam. There are also heavy clays and small amounts of well decomposed peat [Pulikowski 2004].

During the two years of study rainfalls occurred close to the long-term average of $587 \mathrm{~mm}$.

Table 1. Monthly and annual precipitation totals $(\mathrm{mm})$ at particular experimental object

\begin{tabular}{|c|c|c|c|c|c|c|c|c|c|c|c|c|c|c|}
\hline \multirow{2}{*}{$\begin{array}{l}\text { Meteorological } \\
\text { station (object) }\end{array}$} & \multirow{2}{*}{ Years } & \multicolumn{12}{|c|}{ Months } & \multirow{2}{*}{ Year } \\
\hline & & $X I$ & XII & I & II & III & IV & V & VI & VII & VIII & IX & $x$ & \\
\hline \multirow{4}{*}{$\begin{array}{l}\text { Szczawno-Zdrój } \\
\text { (Stare Bogaczowice) }\end{array}$} & $1999 / 2000$ & 40 & 26 & 66 & 51 & 65 & 17 & 112 & 56 & 175 & 44 & 69 & 17 & 738 \\
\hline & $2000 / 2001$ & 45 & 20 & 34 & 40 & 70 & 77 & 50 & 80 & 201 & 114 & 122 & 21 & 874 \\
\hline & $2001 / 2002$ & 52 & 57 & 29 & 42 & 35 & 34 & 100 & 64 & 160 & 348 & 65 & 58 & 1044 \\
\hline & $2001 / 2002$ & 32 & 21 & 21 & 40 & 16 & 27 & 28 & 40 & 63 & 108 & 50 & 48 & 494 \\
\hline \multirow{3}{*}{$\begin{array}{l}\text { Ligota Piękna } \\
\text { (Szewce) }\end{array}$} & $1999 / 2000$ & 43 & 31 & 50 & 40 & 94 & 11 & 64 & 25 & 127 & 41 & 28 & 8 & 562 \\
\hline & $2000 / 2001$ & 42 & 33 & 16 & 21 & 79 & 30 & 53 & 85 & 170 & 44 & 107 & 34 & 714 \\
\hline & $2001 / 2002$ & 29 & 32 & 27 & 68 & 37 & 46 & 48 & 48 & 49 & 107 & 36 & 59 & 586 \\
\hline
\end{tabular}


Table 2. Mean monthly and annual air temperatures $\left({ }^{\circ} \mathrm{C}\right)$ at particular experimental object

\begin{tabular}{|c|c|c|c|c|c|c|c|c|c|c|c|c|c|c|}
\hline \multirow{2}{*}{$\begin{array}{l}\text { Meteorological } \\
\text { station (object) }\end{array}$} & \multirow{2}{*}{ Years } & \multicolumn{12}{|c|}{ Months } & \multirow{2}{*}{ Year } \\
\hline & & $X I$ & XII & 1 & II & III & IV & V & $\mathrm{VI}$ & VII & VIII & IX & $x$ & \\
\hline \multirow{3}{*}{$\begin{array}{l}\text { Szczawno-Zdrój } \\
\text { (Stare Bogaczowice) }\end{array}$} & $1999 / 2000$ & 1.7 & 0.2 & -2.0 & 1.8 & 2.9 & 10.7 & 14.0 & 16.7 & 15.0 & 17.0 & 11.9 & 11.3 & 8.4 \\
\hline & $2000 / 2001$ & 6.3 & 1.4 & -0.6 & 0.3 & 2.5 & 6.7 & 13.4 & 13.8 & 17.9 & 18.1 & 11.0 & 11.9 & 8.6 \\
\hline & $2001 / 2002$ & 1.7 & -3.7 & -0.8 & 4.4 & 4.1 & 7.5 & 15.6 & 16.8 & 18.3 & 18.6 & 11.4 & 7.0 & 8.4 \\
\hline \multirow{3}{*}{$\begin{array}{l}\text { Wrocław-Strachowice } \\
\text { (Szewce) }\end{array}$} & $1999 / 2000$ & 3.0 & 1.9 & -0.3 & 3.8 & 5.0 & 12.1 & 15.7 & 17.9 & 16.5 & 19.0 & 13.4 & 12.5 & 10.0 \\
\hline & $2000 / 2001$ & 6.8 & 2.5 & 0.6 & 1.1 & 3.5 & 8.0 & 14.8 & 15.1 & 19.2 & 19.3 & 12.5 & 12.7 & 9.7 \\
\hline & $2001 / 2002$ & 3.4 & -1.7 & 0.6 & 4.9 & 5.3 & 9.0 & 17.0 & 18.2 & 20.1 & 20.6 & 13.6 & 8.2 & 9.9 \\
\hline
\end{tabular}

Year 2000/2001 in which there was a high annual precipitation of $714 \mathrm{~mm}$ is noteworthy. It was the result of, among others, high rainfall that occurred in July $(170 \mathrm{~mm}$ ) (Table 1). The average annual temperature in each year was higher than the average of the long term and ranged from $9.7^{\circ} \mathrm{C}$ to $10.0{ }^{\circ} \mathrm{C}$ (Table. 2 ).

Measurements were taken in measurement cross-sections equipped with triangular Thomson's overflow, staff gauge and limnigraph. Water samples for determination of phosphorus were taken 1-2 times a month.

The calculation of the phosphorus load flowing out from the catchment were based on daily measurements of runoff and periodic analyzes of the composition of the outflowing water. For periods between successive terms of chemical analyzes, phosphorus concentration was determined by linear interpolation:

$$
\mathbf{E}=\sum_{\mathrm{t}=1}^{\mathrm{t}=\mathrm{T}}\left(\overline{\mathbf{Q}}_{\mathrm{t}} \cdot \mathrm{C}_{\mathrm{t}}{ }^{\mathrm{I}}\right)
$$

where: $€ \quad$ - load of contaminants outflowing from catchment during a month, $\mathrm{kg} \cdot \mathrm{ha}^{-1}$,

$\mathrm{C}_{\mathrm{t}}{ }^{\mathrm{I}}$ - determined the average daily value of the concentration of the examined component, for the days of the period between the execution of two consecutive analyzes determined by linear interpolation, $\mathrm{kg} \cdot \mathrm{m}^{-3}$,

$\overline{\mathrm{Q}}_{\mathrm{t}}$ - average daily volume of unit outflow, $\mathrm{m}^{3} \cdot \mathrm{ha}^{-1}$,

$\mathrm{t}-$ next days in the month.

\section{RESULTS AND DISCUSSION}

The load is an objective parameter in order to compare the share of different sources, e.g. point and surface in water pollution of the river or reservoir. The most common calculation period is a year, less common - a day, and in the case of area sources, unit load referenced in addition to the catchment area is in use. While in the case of point sources, for example outflow of the treated wastewater from wastewater treatment plant load is not subject to significant fluctuations over the year, whereas in the case of area sources this variability is very important. Accordingly, the phosphorus load variability was analyzed in subsequent months over 3 consecutive hydrological years.

Loads of phosphorus runoff from the catchment located in the piedmont part of Lower Silesia in each month rarely exceed $0.10 \mathrm{~kg} \mathrm{P} \cdot \mathrm{ha}^{-1}$ (Figure 1.). About size of the annual load decide loads obtained in one or two months. In the first two years there are months of February and March, a period in which the early spring thaw begins, time of intense flow of water from the catchment. During this period, the monthly load exceeds even $0.40 \mathrm{~kg} \mathrm{P} \cdot \mathrm{ha}^{-1}$ (Figure 1). A slightly different situation was found in $2001 / 2002$, the maximum monthly charge was obtained for August, which is directly related to the extremely high rainfall that was recorded in this month (Table 1).

Much lower loads were determined for lowland catchment, located near Wroclaw. The values calculated for each month rarely exceeded the value of $0.01 \mathrm{~kg} \mathrm{P} \cdot \mathrm{ha}^{-1}$. The culmination of load flowing out is a bit more spread in time comparing to catchment located on Sudety Foothill. Much higher loads were observed during the period from January to April. This period has a major impact on the size of phosphorus load, which flows under these conditions throughout the hydrological year. Seasonal nature of phosphorus runoff from catchment is closely related to volatility of the water volume discharged by the river which decides about its size, while the maximum concentration of phosphorus was found in the summertime [Skorbiłowicz, Ofman 2014]. A similar seasonal distribution of loads is obtained for example for nitrogen [Pulikowski et al. 2011b]. 

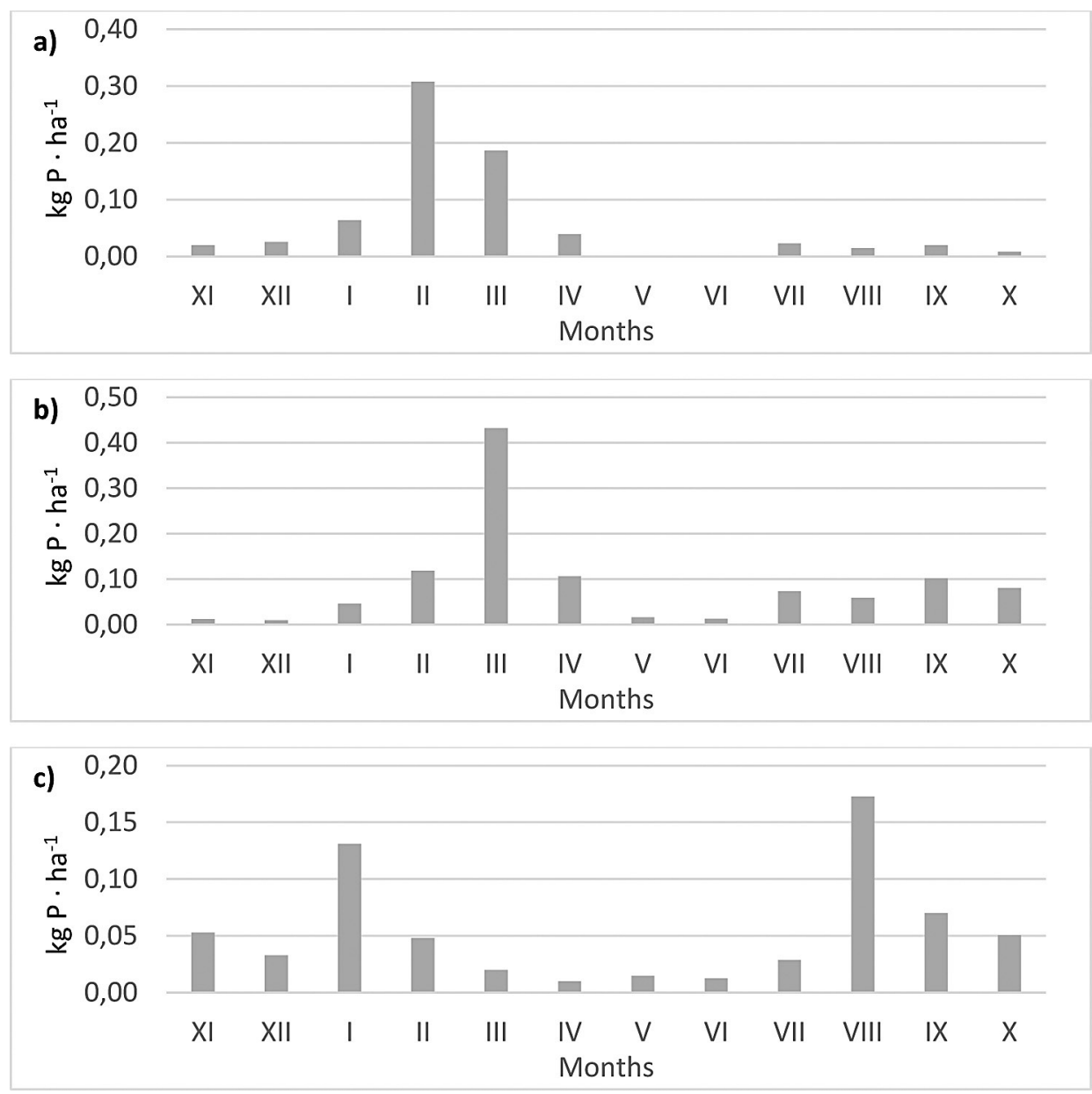

Figure 1. Monthly loads of phosphorus runoff from one hectare of agricultural land in the Sudeten Foreland (Stare Bogaczowice) in the hydrological years: a - 1999/2000, b - 2000/2001, c - 2001-2002

The results clearly indicate that the threat of supply watercourses and water reservoirs in phosphorus compounds from agricultural land, is periodic and is particularly high during early spring.

Phosphorus load flowing out from the analyzed catchment is very diverse (Table 3 ). In the case of a facility located in the Sudety Foothill in the hydrological year 2000/2001 float away even more than $1 \mathrm{~kg} \mathrm{P} \cdot \mathrm{ha}^{-1}$, during study period flowed away average $0.81 \mathrm{~kg} \mathrm{P} \cdot \mathrm{ha}^{-1}$. Significantly lower values were obtained for the second object, aver- aged over the year flowed $0.15 \mathrm{~kg} \mathrm{P} \cdot \mathrm{ha}^{-1}$, and the range of variation was small - from 0.12 to 0.18 $\mathrm{kg} \mathrm{P} \cdot \mathrm{ha}^{-1}$. A similar value $\left(0.13 \mathrm{~kg} \mathrm{P} \cdot \mathrm{ha}^{-1}\right)$ was obtained by Witkowski [1997b]. Such large differences in loads between these objects is likely due to the varying amount of rainfall, and thus a greater unit outflow in piedmont catchment.

The size of load discharged during the year is largely determined by the amount of phosphorus flowing out in the winter (XI and IV). In case of piedmont catchment at this time flowed away on

Table 3. Periodic and annual loads of phosphorus outflow from the catchment area of agricultural. $\mathrm{kg} \mathrm{P} \cdot \mathrm{ha}^{-1}$

\begin{tabular}{|c|c|c|c|c|}
\hline Object & Years & Winter half-year & Summer half-year & Year \\
\hline \multirow{4}{*}{ Stare Bogaczowice } & $1999 / 2000$ & 0.64 & 0.07 & 0.71 \\
\cline { 2 - 5 } & $2000 / 2001$ & 0.73 & 0.34 & 1.07 \\
\cline { 2 - 5 } & $2001 / 2002$ & 0.35 & 0.30 & 0.65 \\
\cline { 2 - 5 } & Mean & $\mathbf{0 . 5 6}$ & $\mathbf{0 . 2 5}$ & $\mathbf{0 . 8 1}$ \\
\hline \multirow{3}{*}{ Szewce } & $1999 / 2000$ & 0.09 & 0.03 & 0.12 \\
\cline { 2 - 5 } & $2000 / 2001$ & 0.13 & 0.05 & 0.18 \\
\cline { 2 - 5 } & $2001 / 2002$ & 0.13 & 0.03 & 0.16 \\
\cline { 2 - 5 } & Mean & $\mathbf{0 . 1 1}$ & $\mathbf{0 . 0 4}$ & $\mathbf{0 . 1 5}$ \\
\hline
\end{tabular}


average $0.56 \mathrm{~kg} \mathrm{P} \cdot \mathrm{ha}^{-1}$ (Table 3), which represents $69 \%$ of annual load, in the case of lowland catchment, this percentage was slightly higher and amounted to $73 \%$. Studies in Canada have shown that in the same period of melting snow, flows $20 \%$ of the annual phosphorus load [Su et al. 2011].

\section{CONCLUSION}

Loads of phosphorus runoff from the catchment located in the piedmont part of Lower Silesia in each month rarely exceed $0.10 \mathrm{~kg} \mathrm{P} \cdot \mathrm{ha}^{-1}$. The size of the annual load is determined by the loads obtained in the two months of early-spring. Much lower loads were determined for lowland catchment, located near Wroclaw. The values calculated for each month rarely exceed the value of 0.01 $\mathrm{kg} \mathrm{P} \cdot \mathrm{ha}^{-1}$. The culmination of loads outflowing is a bit more spread in time compared with the object located at the foothills of the Sudety. Much higher loads were observed during the period from January to April. This period has a major impact on the size of the phosphorus load, which flows under these conditions throughout hydrological year.

The results clearly indicate that the threat of supply watercourses and water reservoirs in phosphorus compounds from agricultural land, is periodic and is particularly high during the early spring.

Phosphorus load flowing out from the analyzed catchment is very diverse. From a facility located in the foothills of the Sudety during hydrological year, average in the study period flowed $0.81 \mathrm{~kg} \mathrm{P} \cdot \mathrm{ha}^{-1}$, significantly lower values were obtained for the second object, on average, in the year flowed $0.15 \mathrm{~kg} \mathrm{P} \cdot \mathrm{ha}^{-1}$. About the size of load discharged during the year largely determines the amount of phosphorus flowing out in the winter (XI and IV). In case of piedmont catchment at this time flowed away on average $0.56 \mathrm{~kg} \mathrm{P} \cdot$ ha- 1 (Table 3), which represents $69 \%$ of annual load, in the case of lowland catchment, this percentage was slightly higher and amounted to $73 \%$.

\section{REFERENCES}

1. Banaszuk P., Krasowska M., Kamocki A. 2009. Źródła azotu i fosforu oraz drogi ich migracji podczas wezbrania roztopowego w małej zlewni rolniczej. Woda-Środowisko-Obszary Wiejskie, 9(4), 5-26.

2. Ekholm P., Kallio K., Salo S., Pietiläinen O.P., Rekolainen S., Laine Y., Joukola M. (2000) Relationship between catchment characteristic and nutrient concentrations in an agricultural river system. Water Research 34(15), 3709-3716.

3. Dąbrowska J. 2008. Ocena zawartości związków azotu i fosforu w wodach rzeki Trzemy. Infrastruktura i ekologia terenów wiejskich, 7, 57-68.

4. Dąbrowska J., Kempa O., Markowska J., Sobota J. 2014. Mściwojów reservoir - study of a small retention reservoir with an innovative water selfpurification system. J. Ecol. Eng. 15(2), 7-16.

5. Czaban S. [ed.]. 2009. Assessment of anthropogenic impacts on water bodies in agricultural catchment. Monografia, seria Współczesne Problemy Inżynierii Środowiska nr 15, Wyd. UP we Wrocławiu, pp. 80.

6. Dojlido J.R. 1995. Chemia wód powierzchniowych. Wyd. Ekonomia i Środowisko, Białystok, pp. 342.

7. Gardner C.M.K., Cooper D.M. Hughes S. 2002. Phosphorus in soils and field drainage water in the Thame catchment, UK. The Science of the Total Environment, 282/283, 253-262.

8. Karczmarczyk A, Bus A. 2014. Testing of reactive materials for phosphorus removal from water and wastewater - comparative study. Ann. Warsaw Univ. of Life Sci. - SGGW, Land Reclam. 46 (1), 57-67.

9. Pietrzak S. 2005. Optymalizacja wykorzystania azotu i fosforu w gospodarstwach prowadzących chów bydła mlecznego na Podlasiu. Woda-ŚrodowiskoObszary Wiejskie, Rozp. nauk. i mongr., 13, 129.

10. Pulikowski K. 2002. Zależność między wartościami wskaźników zanieczyszczenia a objętością przepływu w małych ciekach. Zesz. Probl. PNR Warszawa, 487, 295-303.

11. Pulikowski K. 2004. Zanieczyszczenia obszarowe w małych zlewniach rolniczych. Zesz. Nauk. AR we Wrocławiu, ser. Rozprawy CCXI, 479, 137.

12. Pulikowski K., Orzepowski W., Pokładek R. 2011. Water quality in agriculturally used catchments in Lower Silesia. Wyd. UP we Wrocławiu, Monografia CXXXVII, ser. Współczesne problemy inżynierii środowiska XVIII, 94.

13. Pulikowski K., Czyżyk F., Pawęska K., Strzelczyk M. 2011. Sezonowe zmiany wielkości ładunku azotu odpływającego z mikrozlewni użytkowanych rolniczo. Infrastruktura i Ekologia Terenów Wiejskich, 10, 161-171.

14. Sapek A. 2008. Nawożenie fosforem a jego skutki w środowisku, Woda-Środowisko-Obszary Wiejskie, 8, 2b(24), 127-137.

15. Sapek A. 2009. Fosfor w łańcuchu pokarmowym człowieka a środowisko w Polsce. Inżynieria Ekologiczna, 21, 62-72.

16. Skorbiłowicz M. Czynniki i procesy kształtujące obieg składników mineralnych w wodach rzecznych zlewni górnej Narwi. Rozprawy Naukowe nr 197. Wyd. Politechniki Białostockiej, 2010. 
17. Skorbiłowicz M., Ofman P. 2014. Seasonal changes of nitrogen and phosphorus concentration in Supraśl river. Journal of Ecological Engineering 15(1), 26-31.

18. Sojka M., Murat-Błażejewska S., Kanclerz J. 2008. Ocena oddziaływań antropogenicznych o charakterze obszarowym na jakość wód Strugi Dormowskiej. Acta Scientiarum Polonorum, Formatio Circumiectus 7(2), 15-28.

19. Su J., J. van Bochove E., Thériault G., Novotna B., Khaldoune J., Denault J.T., Zhou J., Nolin M., C., Hu C., X., Bernier M., Benoy G., Xing Z.S., Chow
L. 2011. Effects of snowmelt on phosphorus and sediment losses from agricultural watersheds in Eastern Canada. Agricultural Water Management 98, 867-876.

20. Witkowski D. 1997a. Wybrane czynniki kształtujące jakość wód powierzchniowych w małych zlewniach nizinnych. Roczn. Glebzn. t. XLVIII, 3/4, 5-21.

21. Witkowski D. 1997b. Składniki nawozowe w dwóch małych zlewniach o zróżnicowanych właściwościach glebowo-rolniczych. Roczn. Glebzn. t. XLVIII 3/4, 23-36. 